\title{
Archaic leprosy law under attack
}

At last, Japan is considering whether to repeal its archaic Leprosy Prevention Law, which now confines more than 5,800 people to a life of isolation. The law was introduced in 1907 after the first International Leprosy Congress of 1897. It has been amended on two occasions, in 1931 and 1953, although not significantly, and the requirement for compulsory isolation remains.

If the law is changed, it will be as much symbolic as anything (as much of the law is no longer enforced), but the question of the future financial support and housing of patients who are presently institutionalized remains. Patients could stand to lose these benefits if the law is changed.

Many feel that a change in the law could represent a turning point for patients rights in Japan, particularly among groups of people (such as those with AIDS and psychiatric disorders) who have been subject to discrimination.

Part of the renewed interest in abolishing the law came in the end - from the media and human rights groups, following a rigorous debate in the late 1980 s on how to deal with AIDS in Japan. At that time, some commentators called for people with AIDS and the human immunodeficiency virus to be isolated from society, bringing, once again, the issue of patient rights and discrimination to the fore.

Indeed, the Japanese Leprosy Association made a public apology this April for not having acted sooner, and called for the law to be repealed immediately. This follows similar calls from other organizations, including the Federation of Directors of National Hansen Disease (Leprosy) institutions and the influential Japanese Leprosy Foundation (Tofukyokai), which is affiliated with Japan's Ministry of Health and Welfare.

A recent editorial in the Mainichi Shimbun, one of Japan's leading newspapers, also called for the law to be repealed and cautioned: "Our harsh and ignominious experience with lepers in our midst should not be repeated as we address the rising challenge of AIDS."

People with leprosy in Japan have

been subject to considerable prejudice and discrimination - much of it through ignorance, misinformation and scaremongering. Although the more advanced forms of the disease can be disfiguring (involving crippling deformities and loss of tissue, often of the fingers and toes), the disease has - since the late 1940s - been treatable with Dapsone, a drug originally developed for the treatment of tuberculosis. (New cases of leprosy are now treated on an outpatient basis with a combination of drugs that halt progression of the disease within a few days.)

\section{IMAGE UNAVAILABLE FOR COPYRIGHT REASONS}

stitutionalized before 1955 and have had little or no experience of life on the outside. Although, technically, the law prohibits patients from leaving the institutions, it is not enforced and people are now able to come and go as they please.

Life, however, was not always so free and easy, says Kenjiro Toda of the National Council of Hansen Disease Patients, a lobby group set up in the early 1950s. In 1953, hundreds of patients defied the law and left the institutions to demonstrate outside government buildings. In spite of lobbying at the time from the International Leprosy Association and the World Health Organization (WHO), Japanese authorities decided against abolishing the law.

Having lost that battle to have the law repealed, the National Council of Hansen Disease Patients chose instead to focus its efforts on combating discrimination and on improving living conditions in the institutions. "It used to be a bit like a prison," says Toda, but conditions have improved.

The Japanese government spends Y40 billion (US\$468

Interestingly, most national newspapers and publications in Japan consider it discriminatory to refer to the disease as raibyo (leprosy), preferring instead to call it Hansen's disease after the Norwegian doctor who, in 1873, discovered the Mycobacterium leprae bacillus that causes leprosy.

There are currently 15 'National Institutions' in Japan. About 700 'patients' live at Tama-zenshoen, one of the largest, located just outside Tokyo. The people at the institutions are still referred to as patients even though the disease has been arrested and rendered noninfectious in many of them. The average age of patients in the institutions is 70 , and some have lived there for nearly 50 years.

Tama-zenshoen occupies an area of about one-third of a square kilometre and consists of four hospitals and about 100 apartments. Most of the patients were isolated in their teens or early twenties; almost all (more than 90\%) were in- million) a year running the
institutions. Patients are provided with free board and lodging and each receives a monthly allowance of $¥ 80,000$ (US\$936).

There are now annually between 10 and 20 reported cases of leprosy in Japan; most of these are immigrant workers. The WHO currently estimates that worldwide about $2,400,000$ people are infected with leprosy.

A senior government official in the Infectious Disease Control Division of the health ministry, which has responsibility for leprosy, said the issue will be considered carefully but that no decision had yet been made on whether to repeal the law, but that the health ministry was in the process of setting up a special committee to consider if and how the law should be changed. If the law is repealed, however, many feel it will be an important victory over prejudice and a step forward for Japanese democracy.

RICHARD NATHAN

Tokyo 